\title{
The Deuteronomic roots of postexilic prophetic eschatology in Malachi
}

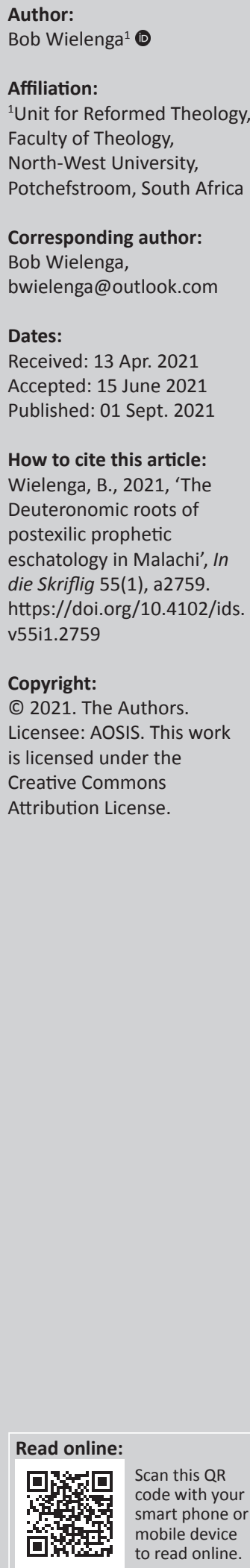

In this article, the promises of judgement and restoration in Deuteronomy 4:25-31; 28:15-68; 30:1-10 are compared with the eschatological prophecies in Malachi 2:17-3:24 about the Day of the Lord. The conclusion is that Malachi's eschatology can be understood against the background of the history of fulfilment of these promises as envisioned in the Torath Mosheh in Deuteronomy. The rhetorical nature of Moses' speeches is taken into consideration, indicating their communicative intent to persuade the people to take the promise of judgement seriously and to return to God in compliance with Mosaic teachings in order to avert it. But even beyond judgement, restoration is promised as well, indicating the positive intent of judgement preaching. The purpose of the announcement of judgement is to delay its fulfilment; its irrevocability only shows when the response to the teachings of Moses is persistently negative. The promises of judgement are not meant to be understood as prognostications to be fulfilled within a predetermined time frame. They are delayintended, and hence avertible. These features of Mosaic teaching in Deuteronomy can be identified in Malachi's eschatology which is shaped by divine judgement but is delayintended and in compliance with the Mosaic teachings in Deuteronomy, theocentric and temple-based.

Contribution: The purpose of this article is to contribute towards a theological reading of Malachi in the context of the metanarrative of the Old Testament (OT) Scriptures.

Keywords: Malachi's eschatology; Deuteronomy's exilic warnings; exile as reversal of the exodus; anonymity of exilic locations in Deuteronomy; OT's delay-intended eschatology.

\section{Introduction}

In this section, firstly the research question is formulated; thereafter, attention will be paid to the hermeneutics of Deuteronomy employed in this research; this will lastly be followed by an outline of the article.

\section{Research question}

In this article, the question is investigated how the eschatological prophecies of Malachi (Ml) 2:17-3:24 could have been influenced by Deuteronomy (Dt) 4:25-31; 28:15-68 and 30:1-10.

These Deuteronomic texts are usually understood as referring to the Babylonian exile of Israel and its return home afterwards (597-539 bce). In this investigation, the option is chosen to read them as referring to any divine-initiated future loss of land and to return to it afterwards in general. The Babylonian exile occurred to be a stage in the developing covenant history of God with his people in the land He had promised to give to their ancestors. The Deuteronomic texts could be re-appropriated in the postexilic era in support of Malachi's eschatological prophecies of the Day of the Lord.

Decisive in this research is the acknowledgement of the authoritative position of Moses in the postexilic community. His teaching (the Torath Mosheh ${ }^{1}$ ) was normative in all aspects of life (Ezr 3:2-4; 6:18; 7:10), ${ }^{2}$ comprising the words spoken by Moses, the servant of the Lord (Dt 34:5) in whose mouth God puts his words (Dt 18:18) and whose incomparability as a prophet was

1.Even though the term Torath Mosheh only appears in Mi $3: 22$, it can be aptly used as description of the Deuteronomic teaching throughout the OT.

2.For the expression Torath Mosheh in Malachi 3:22, see Wielenga (2019:3). There is no need, certainly not in the postexilic era, to sharply distinguish between the different possibilities (Pentateuch, Deuteronomy or 'Deuteronomic Code'). Deuteronomy is certainly predominant in Malachi. It suggests at least intentional thematic connections between Deuteronomy and Malachi (Wielenga 2019 7-8). See Wielenga (2016:7-8) for a discussion about the canonical position of Malachi 3:22-24 especially in Malachi and the OT in general. For Deuteronomy, see Block and Schulz (2017). 
undiminished in the postexilic era (Ml 3:22) (Block 2017:1937). The teaching of God's words as mediated by Moses (Dt $4: 1,14 ; 5: 27,31)$ and written down by him and kept next to the Ark in which God's written Ten Words were deposited (Dt 10:3-5; 31:9-13), is strongly emphasised right from the beginning. Deuteronomy as a textualised format of Moses' teachings was published to ensure the perpetuation of his teaching ministry into the future. Hence the strong warning against 'forgetting' Moses' teaching, unconsciously (Dt 4:9) or intentionally (Dt 8:11)! 'Remembering' Moses' teaching of God's words (Dt 1:3) meant life, and 'forgetting' them, death. ${ }^{3}$

Scholarly consensus exists around the influence of the Deuteronomic covenant traditions in Malachi (Assis 2012:212-219; McKenzie \& Wallace 1983:549-563; O’Brien 1990:85-107; Weyde 2000:37-47). ${ }^{4}$ The influence of the Deuteronomic conceptualisation of covenant is evident from Malachi's approach to the temple ministries (Ml 1:6-2:9), or from his rejection of the ill-treatment of women in divorce and remarriage procedures (Ml 2:10-14), or of immigrants in the societal context (Ml 3:5) (Wielenga 2019; 2020). The covenant relationship between God, Yahweh Tsebaōth (Ml 1:4) (Wielenga 2019:5), and the remnant population of Persian Yehud, was vertically and horizontally breached, with serious consequences for the future of the repatriated population, his 'holy seed' (Ezr 9:2), (Skafte 2013:50-51). A recurrence of divine judgement, as happened in the still recent exilic past, could take place again.

The advent of the Lord to his temple was already announced: He would come to sit in judgement on his wayward people (Ml 3:1). That would end in a calamity, imagined as a burning furnace leaving nothing but ashes, to take place at an unspecified moment in the future on the so-called Day of the Lord (Ml 3:2,19). This message called to mind the covenant curses of old as taught in the Torath Mosheh (Dt 4:25-29; $28: 15-68 ; 29: 20-28)$.

This threatening recurrence of divine judgement due to transgressions that were similar to the pre-exilic ones (Zch 1:2-6; Is $56: 9-57: 12 ; 65: 1-7)$, brings up the question of how much Malachi has been influenced by Moses' prophecies regarding divine judgement and restoration in the future of the people's history in the promised land.

In this article, the two sets of texts is compared, approaching them rethorically (synchronically), with the intention to show that Moses' authoritative teaching about future loss of land, as result of divine punishment, has indeed influenced Malachi's prophecy of the eschatological Day of the Lord. As a result of this investigation, the coherence of the Old Testament position on eschatology will be confirmed.

\section{See Coetsee (2019:101-126) for "life' and "death' in Deuteronomy.}

4.For a short overview of the scholarly debate about conditional or unconditional covenant in Deuteronomy, see Hwang (2012:155-177) and Turne (2013:203-208).

\section{Hermeneutics of Deuteronomy}

A short remark is made about how Deuteronomy is read in this article. ${ }^{5}$ It is taken in its canonical, final form as found in the Old Testament (MT). ${ }^{6}$ Deuteronomy is presented here as a unified text with a clear narrative development, coherently structured, orderly narrating what happened in the narrative time with a distinct communicative intent (Sonnet 2012:198; Vogt 2013:62, see Otto 2007:19). A rhetorical (synchronic) rather than a historical-critical (diachronic) approach is followed in this article.

Two audiences can be distinguished in Deuteronomy.

Firstly, there is the actual audience addressed by the narrator in the narrational time through his textualised narrative, read or listened to by the coming generations in their own historical contexts. His purpose was to persuade them to receive Moses' God-given teachings (Dt 1:3) as decisive for their own lives in the promised land as people covenanted to God. Among this audience, Malachi, ${ }^{7}$ halfway through the 5 th century BCE, can be counted.

The other audience is the implied one in the narrated time of Moses, from whose perspective the narrator describes what occurred at this crucial moment of covenant renewal in the fields of Moab on this side of the river Jordan. Hence, he frames this perspective in the form of Moses' prophetic farewell speeches before his death (Dt 1:5; 34:9), preparing the people for their life in the promised land at the other side of the river Jordan. This assumes a context that matches better the anti-royalist and egalitarian ideology, espoused in Deuteronomy 12-26, than the widely proposed monarchical one in the seventh to sixth century BCE (McConville 2002:33-48; Vogt 2013:66-72). ${ }^{8}$ The narrator sometimes breaks into Moses' narrative through the so-called frame breaks, as can be found in Deuteronomy 2-3 (Wielenga 2017:284-285), providing post-Mosaic information to back up Moses' narrative as transmitted by the narrator who, by doing so, enhances the reliability of Moses' narrative for the later audiences as in Malachi's time (Sonnet 2012:199-203).

Both audiences, being part of the one covenant of God, are transgenerationally united (Hwang 2012:233-234) and are facing the same charge to observe Moses' God-given teachings (Torath Mosheh) in their own specific historical contexts.

5.The literature about the provenance of Deuteronomy is expansive. It is not within the scope of this article to discuss and defend the position taken here. Authors like Arnold (2017), Block (2001), McConville (2002), Sonnet (2012) and Vogt (2003; 2013) inform the position taken in this article. See also Wielenga (2017:284-285)

6.We follow in both Deuteronomy and Malachi the chapter and verse division of the Masoretic Text of the OT.

7.About Malachi as a historical prophet, see Tiemeyer (2005a:178) and Snyman (2015:24-27). For the date of the book Malachi, see Snyman (2015:3-5).

8.This suggests an earlier date for Deuteronomy than usually is assumed, at least premonarchical. This does not mean, though, that Deuteronomy was written and published in the Mosaic era (Arnold 2010:53-72). See Otto (2007:1-22) for a short introduction to modern Deuteronomy research. 


\section{Outline}

Following these two introductory paragraphs are sections summarising the eschatology of Malachi and the reading of the relevant texts in Deuteronomy $(4: 25-31 ; 28: 15-68$ and 30:1-10).

This will be concluded by comparing the results of these two investigations, to formulate an answer to the research question of how Malachi could have understood and applied Moses' prophetic teaching in his own prophetic ministry.

\section{Summary of Malachi's prophetic eschatology}

Three main features of Malachi's eschatology ${ }^{9}$ will be discussed in the context of the eschatological tradition of exilic and postexilic prophecy. Firstly, attention will be paid to his theocentric, temple-based eschatology; next, the significance of the role that divine judgement played in his concept will be looked into; and lastly, the delay of the Day of the Lord will be studied as an integral part of his eschatology.

\section{Temple-based eschatology}

Built as it is upon the eschatological tradition developed by Ezekiel, Joel, Haggai and Zechariah (Wielenga 2016; 2018; 2020), Malachi's theocentric eschatology should be understood as temple based. Central in his eschatology, is the temple as the place of worship chosen by God to establish his name there in his dwelling. In this context, his incisive critique of the negligence by the temple-staff of the ministries they were covenanted to ( $\mathrm{Ml} 2: 5-8)$, comprising the main part of his book (1:6-2:9; 3:3-4, 8-10), must be understood. Their casual handling of their altar duties and the disregard for their teaching ministry (of the Torath Mosheh), amounted to profanation of God's holy name (Ml 1:6; 2:5). ${ }^{10}$ The failing temple worship demotivated the people to live sanctified lives. ${ }^{11}$ This vertical and horizontal breach of the covenant introduced into the postexilic eschatological discourse the issue of divine judgement on the Day of the Lord (Ml 3:1-3, 17, 19, 21). In Malachi 3:2-4, the prophet's communicative intent with his judgement preaching is obviously to persuade the people to return to God and reform the temple worship up to the standards of the Torath Mosheh (Ml 3:2-3).

Malachi's message must be read against the background of Deuteronomy 12:5, 11 (Wielenga 2019:5-7). The establishment of God's name in the chosen place, in Malachi's time evidently the temple in Jerusalem, signified that God himself was present there and that in his presence his people should worship him with joy. The careful observance of the temple worship, watched over by its staff, should shape society into

9.For a discussion about the term prophetic eschatology, see Wielenga (2018:2-4) with literature references.

10.For the significance of the name Yahweh Tsebaōth in Malachi, see Wielenga (2019:5) with reference to Rose (2012:186-187).

11.As mentioned above, the abuse of women in divorce and remarriage practices, or the ill-treatment of socially vulnerable people like widows, orphans and immigrants come to mind. a sanctified community with a distinctly anti-Canaanite character (Dt 7:1-6; 12:2-4). In the postexilic time, remembering the law of Moses (Ml 3:22) meant to put the temple right in the centre of the life of the nation, for Yahweh Tsebaōth dwelled there among them. In the postexilic time, this theocentric perspective was strongly influenced by Ezekiel's prophecies.

The exilic prophet Ezekiel envisioned (in 573 BCE [Ezk 40:1]) the postexilic future of the returned exiles in a tribally reordered land around the 'sacred portion', where God would dwell in the centre in a beautifully reconstructed temple, partitioned off by a wall from the rest of the land, to enhance its holiness (Ezk 40-41). Only after God's return to the temple (Ezk 43:1-5) would the altar ministry be started up again (Ezk 43:13-27). From the temple outwards peace like a river would cover the earth (Ezk 47:1-12). This (proto-) apocalyptic image is alluded to in Haggai 2:6-9, 20-23 and Malachi 3:20. The eschatological future starts from the temple outwards, because it starts with God whose compassions are new every morning, also beyond the judgement of exile (Lm 3:22-23) (Wielenga 2020:5-6).

\section{Judgement shaped eschatology}

The seriousness of the lapse in temple worship in violation of the Torath Mosheh, is disclosed by Malachi with appalling examples, as indicated above. Divine judgement over the spiritually deplorable situation among the repatriated remnant population in Persian Yehud, is envisioned as a refiner's fire or burning furnace (Ml 3:2-3, 19). ${ }^{12}$ These two images of the same divine judgement on the Day of the Lord, refer to the reality of a division among the people between a minority of God-seekers (Ml 3:16-18) and the majority of God-forsakers (3:19) (Wielenga 2016:4-5). For the first category, there is hope beyond judgement, Malachi 3:18, alluding to Ezekiel's perspective in Ezekiel 40-48. Ezekiel, and followed later by Haggai in 2:6-9, 20-23, announced eschatological peace beyond judgement (Ezk 38-39) (Block 2013:95-100). But for the second category, there is no hope, because a burning furnace does not leave anything but ashes.

Like Ezekiel's message of divine judgement over the repatriated exiles after their return home (Ezk 38:8), Malachi too announces divine judgement once more, only half a century after the first exile, in the unspecified eschatological future on the Day of the Lord. However, he also follows Ezekiel in his comforting message of God's compassionate intervention on behalf of his people, granting them peace after the defeat of their enemies (Ml 3:20, 24) (see also $\mathrm{Hg}$ $2: 6-9,20-23)$. A theocentric, temple-based future is also Malachi's message of hope, but it is beyond judgement, which is imagined as a refiner's fire. The God-seekers will suffer divine judgement together with the God-forsakers, but for them the outcome will be radically opposite. This message of judgement is intended to persuade the people in the in-

12.For Malachi's introduction of divine judgement in his eschatological discourse influenced by predecessors like Ezekiel and Joel, see Wielenga (2018:2-3: 2020:5-6). 
between time, to reform their lives in compliance with the Torath Mosheh, with a view to the future. ${ }^{13}$

\section{Delay-intended eschatology}

The explanation of Malachi 3:1a is contested among scholars (Wielenga 2016:6). In this article, the messenger of the Lord is identified with prophets like Malachi and the eschatological Elijah in Malachi 3:23. They are sent before the Lord comes to his temple on his Day of judgement. The advent of the Lord will be sudden, an eschatological time indicator that stresses the imminence and urgency of his intervention in his people's life. The present is calamitous and needs the urgent intervention of a just and compassionate God to solve the situation, being faithful to his promises of old (Ml 1:2). The prophetic ministry calls up the people to prepare themselves in fear and with expectation for the arrival of their Lord.

This type of prophecy is not meant as a prognostication of future events within a historical time frame, ${ }^{14}$ suggesting a predetermined time path for the fulfilment of the judgement prophecy, unrelated to the responses of God's people to the prophetic judgement preaching. ${ }^{15}$ How long the in-between time will take till judgement arrives, depends on how the two partners in the asymmetrical but mutual covenant relationship respond to the judgement prophecy and its effects. On the one hand, it depends on the response of the audience addressed, but on the other hand, it is contingent on the resolution of a just and compassionate God. ${ }^{16}$ As Judge, he opens the court procedures at his time.

The conditionality of prophetic preaching ( $\mathrm{Ml} \mathrm{2:2} \mathrm{[if]),}$ assumes that the judgement announced will not be executed without giving the people the opportunity to return to God, in the process averting it. It is not an irreversible future fate that awaits them, despite their response.

However, without a positive response, it is irrevocable. The twin images of judgement as a refiner's fire and a burning furnace also assume that a definitive judgement can be averted. That is explicitly the rhetorical intent of this type of prophecy.

The conditionality of Malachi's judgement prophecy is also apparent from the charge in Malachi 3:22, to remember the Torath Mosheh in the interim before the eschatological advent of the Lord to his temple. In order to remember, the people must be taught how to live according to Moses' instructions (Wielenga 2019:3). This is predicated on a compassionate

13.Similarities between Ezekiel's theology of exile and Deuteronomy are pointed out by Gile (2013:300-302). For the influence of Ezekiel's perspective on exile in Malachi via Haggai, see Wielenga (2020:6). Deuteronomy could also have been a common tradition that has influenced both prophets' eschatology.

14.See the volume of studies edited by Hays (2016) for the following argument; see also Tiemeyer (2005b), and Wielenga (2018).

15.The eschatological time indicators sudden in Malachi 3:1b, or after many days in Ezekiel 38:8, refer rhetorically to the imminence and urgency of the expected Day of the Lord.

16.The concept of co-dependence (or dual causality, Sonnet 2016:73-74) originates from the unilateral and bilateral structured mutual but asymmetrical covenant, as conceptualised in Deuteronomy. The responses of both partners are kept togethe in a tension distinctive for such a covenant (Wielenga 1998:53-126; 2018:5).
God who grants the time needed to complete this ministry, resulting in the possible deferral of his advent as Judge on the Day of the Lord. It creates space to receive grace granted by a faithful God, who does not forget his promises made to the ancestors (Ml 1:2).

Judgement prophecy does not aim at a literalistic fulfilment of what has been announced but intends to achieve just the opposite: its non-fulfilment! Each positive step in this intended direction, namely the return to God in compliance with the Torath Mosheh, ought to be interpreted as a partial fulfilment and defers the ultimate judgement even further. Eschatological peace beyond judgement (Ml 3:20) is postponed in this process as well, a necessary side-effect of God's compassionate interactions with his people. Yet, this delay is inherently a positive concept, creating space and time for a remorseful return to God. Postponement of the future of peace beyond judgement (Ml 3:20), implying the prolongation of the suffering in the interim, is the other side of the same coin of postexilic prophetic eschatology, as encountered in Malachi (Wielenga 2018:5, 7).

\section{Summary of Deuteronomy's so-called exilic texts}

In this section, two subjects will be addressed. Firstly, the texts will be identified that could have influenced Malachi's prophetic eschatology, and secondly, the relevant texts identified will be studied.

\section{Introduction}

The identification of Deuteronomy 4:25-31, 28:15-68 and 30:1-10 as texts that could have influenced Malachi's prophetic eschatology, rests upon the appreciation of the rhetorical scheme of journey through time and place, as decisive for understanding the message of Deuteronomy (Millar 1994:15-88). Central to this message is the journey of Israel to the land promised by God to their ancestors (Gn 12:3), from Egypt via Horeb to Kadesh-Barnea, where the people chose not to enter the land due to their lack of faith (Dt 1:32-33). This resulted in a reversal of the exodus (Dt 2:1). They received a second chance to enter the land at the end of their 38-year wilderness journey at Moab (Dt 1:1; 2:2). Here Moses addressed them during a religious renewal ceremony, updating the covenant concluded at Horeb, in preparation for their conquest and occupation of the land. The journey would be continued inside the land via places chosen by God like Mount Ebal (Dt 27:1-8), such as Bethel, Shechem and Shiloh where the covenant, concluded at Horeb and updated at Moab, could be renewed during the annual festivals. At each of these places, Israel had to recommit themselves to God in compliance with the Thorath Mosheh in the presence of God, who dwelled at those places chosen by him and where alone they had to worship him (Dt 12:6-7) (McConville 1994:120). In postexilic times, the temple in Jerusalem was the chosen place, continuing the pre-exilic monarchical tradition (2 Sm 7; 24; 1 Ki 8). 
In the land, Israel should worship God in word and deed in order to be a blessing to the nations, which was the third promise of God to Abraham (Gn 12:3, see Ex 19:5-6; Dt 4:5-8; $26: 19 ; 28: 9-10)$. This was also the goal of the journey that God started with Israel in the patriarchal past (Block 2011a:140161; Wright 2006:258, 261). Possession of the land as a divine gift was, however, dependent on the Torah-compliance in covenant faithfulness before the eyes of the watching nations. In this context, the unceasing admonition finds its justification to worship God alone in his way (Dt 5:7-8, 12:4) and to obliterate everything that would detract them from true worship (Dt 4:15-20; 7:1-6). Worshipping man-made gods of wood and stone (Dt 4:28; 29:16-21), was not just blasphemy in breach of the first and second commandments of the Decalogue, but it would also prevent Israel from becoming a blessing to the nations. On the contrary, they would become in the end an object of ridicule and even of horror to the nations (Dt 28:25, 37; 29:22-28) (Turner 2013:210-211). Indeed, idolatry would lead to loss of land, for it would destroy the reason for the people staying there in the first place: to be a blessing to the nations. Staying in the land would have then lost its meaning. But the loss of land did not lead to the loss of covenant. In his grace, God would keep the journey going, back to the land (Dt 30:1-10), faithful to his promises to their ancestors.

\section{Deuteronomy 4:25-31}

A full explanation of this section is beyond the scope of this article, but those elements that are relevant for understanding Malachi's prophetic eschatology, will be selected.

The communicative intent of Moses' warning 'today' at Moab (that they would 'quickly perish' from the land, Dt $4: 26 ; 11: 17)$, is to persuade the people to stay on course in the land and to continue to reject any idolatry (Dt 4:25). It is not intended to be a prognostication of future developments that would happen without delay (against Turner 2011:109; Vang 2011:27-30). This interpretation misses the rhetorical intent of Moses' speeches, to spiritually prepare the people for the task ahead in compliance with the Torath Mosheh.

Moses was realistic about the ability of Israel to stay on course in the land, with the memory of their failures during the wilderness journey still fresh in his mind (Dt 1-3) (Millar 1994:16-32). ${ }^{17}$ Hence, during their journey inside the land, at the places chosen by God, they would receive the opportunity to renew their covenant commitment to God and to atone for their failures in Torah-compliance. ${ }^{18}$ The threat of loss of land is enclosed in a framework of opportunities for liturgical renewal, in accordance with the covenant context of Moses' speeches. God mercifully kept in his faithfulness the way

17.Turner (2011:114-115) translates kî temporally as when in Deuteronomy 4:25, 29 indicating a future prediction. The choice between a temporal and a conditional translation (if), is in this rhetorical context more ambiguous and less important. Between optimism and pessimism re Israel's ability to stay on course (Turner 2013:212-215), one should discern a third option: realism, keeping the negative 2013:212-215), one should discern a third option: realism, keeping the negative
and positive aspects together in covenantal tension. See here also Smith (2013:364) discussing Deuteronomy's influence in Ezra-Nehemiah (Ezr 9:9-11; Neh 1:5-7).

18.See the conclusions of Richter (2007:364-366) re the Mount Ebal ceremony in Deuteronomy 27:1-8. open to the patriarchal covenant: they would return to him after the loss of their land (Dt 4:29-30). They were expected to stay on course faithfully. ${ }^{19}$

Expressions as quickly, or soon should not be understood literally in terms of calendar time. It rhetorically confronts the implied audience with the certainty of the loss of land, stressing the importance of recommitment to God and the Torath Mosheh, without undermining the reality of the threat of judgement (loss of land) in case of persistent disobedience. That would have weakened the persuasive character of the warning. The nearness of the threat of loss of land, should have to be a daily reminder of the seriousness of living in the land in God's holy presence, for the eyes of the watching nations.

\section{Deuteronomy 28:15-68}

Differently from Deuteronomy 4:25-28, Deuteronomy 28:15-68 does not refer to their quick perishing from the land as divine judgement for idolatry. Loss of land is now the final phase in a long history of deteriorating circumstances, the conclusion of a slow reversal of the exodus (Dt 28:64-68). The promises God made to the ancestors (Gn 12:3) (Labuschagne 1997:103; Turner 2011:132, 134, 140) would be cancelled: no land, just a few survivors scattered among the nations, being threatened with the loss of their identity as God's chosen people (Dt 28:64), not being a blessing but a horror to the nations (Dt 28:37).

The intention of Moses' prophetic preaching here, is not to present the loss of land as an inevitable fate that could not have been averted..$^{20}$ The avertability of the loss of land is integrated into the prophetic promise of divine judgement in the context of a mutual, be it asymmetrical, covenant in which the responses of Israel as covenant partner really count in the fulfilment process (Dt 29:2-8) (ed. Hays 2016:94). Judgement is irrevocable, however, but only in case of persistent disobedience, as the postexilic audience could testify. But the announcement of the curses has a communicative intent: to persuade the people to stay on course in remembrance of the Torath Mosheh (Dt 28:1). If they did so, then the curse announcement had attained its objective.

The whole point of Moses' speech is to prevent the loss of land from happening. The insertion of Deuteronomy 27 with its altar and law tablets before Deuteronomy 28 with its blessings and curses, suggests at least that Israel is expected to choose right, and in case of failure, to call upon the Lord's mercies through the sacrificial ministry (Millar 1994:70-74).

19.The Babylonian exile is not named here. Such an identification would have undermined the communicative intent of Moses' warning. For the implied audience, such a specific reference to an unknown, far-away, not yet existing destiny, would not have served its purpose. See Giles (2013:303) for Ancient Near Eastern treaty curses re exile as possible model for Deuteronomy's curses, avoiding the routine dependence upon the Babylonian exile experience for understanding Deuteronomy.

20.Turner (2011:135) stresses the inevitability of the fulfilment of the curses from Deuteronomy 28:45 onward, based upon a declarative translation of kî (because), predicated upon Deuteronomy 29:4. God had not yet given them a circumcised heart; in Deuteronomy 30:6, this would be granted only in the future, in exilic times. This interpretation, however, undercuts the message of Deuteronomy times. This interpretation, however, undercuts the message of Deuteronomy
$30: 19$, where they are assumed to be able to choose between life and death. See also Deuteronomy 30:10. 
This fits in with the reference to the circumcised heart God had not yet given Israel 'to this day' (Dt 29:4). During the wilderness journey they suffered from an uncircumcised heart. They did not live up to the standards of the Torath Mosheh. God, nevertheless, looked after them with love and care, despite his disciplinary interventions (Dt 29:2-8). They could also expect this from God in future in the land as recovenanted people, called to respond from their promised new hearts (Labuschagne 1997:117; Miller 1990:204-208). From a postexilic perspective, this raises the question of whether this new heart had already been given to Israel. The loss of land and the deportation to foreign nations at the end of a long history of judgement and restoration, could only be understood because of Israel's uncircumcised heart. Hence, the condition of Israel's heart in the postexilic era again became an issue of eschatological prophecy, in accordance with Jeremiah 31:31-33; 32:37-41 and Ezekiel 36:22-32.

\section{Deuteronomy 30:1-10}

Among commentators (Cook 2015:216; Labuschagne 1997:144, 150; McConville 2002:424-428; and Turner 2011:227-239), there is some discussion about the translation of Deuteronomy 30:1-3, 10. ${ }^{21}$ The hope of restoration beyond judgement, a return to the land with all ancestral promises fulfilled (Dt 30:3-5), is contingent on divine intervention, but dependent on Israel's remorseful return to God as well. This does not discount the primacy of God's actions over those of Israel..$^{22}$ This is already expressed in Deuteronomy 4:30; 30:1. At a certain moment during their dispersal among the nations, the Torath Mosheh about blessings and curses will 'come upon you and you will take it to heart', an unmistakable sign of a divine initiative on behalf of his people to which they will positively respond.

Moses concludes this part of his speech with a peroration (McConville 2002:243) in which the Moab-generation is called upon to make the decisive choice between life and death (Dt 30:19-20). This choice could be made in view of what God had revealed to Israel through Moses (Dt 29:29), signifying that making the right choice was attainable (Dt 30:11-15). However, realistically, Moses stresses the gravity of their choice by again giving the warning of quickly perishing from the land in case of failure to comply with the Torath Mosheh (Dt 4:26; 30:18). ${ }^{23}$

In this context, the promise is given of restoration beyond judgement, not as a prognostication of an irreversible event,

21.Should kî be translated conditional, temporal or causative, referring to the theological problem of the primacy of God's grace over the obedience of the people? In Deuteronomy, a dual causality within the context of an asymmetrica but mutual covenant is decisive, eliminating any unholy competition between both covenant partners.

22.This is numerically expressed in Deuteronomy 30:1-10 in God as acting agent in 11 scenes, with Israel in seven scenes (Labuschagne 1997:141).

23.In this context of realism and warning, Deuteronomy 31:16-20, 27, 29 functions; notice the call to the elders in $31: 28$, to take seriously their responsibility to teach the Song of Moses. Future loss of land should not come as a surprise, when it happened. but as a promise of a compassionate God who is faithful to his promises to the ancestors (Dt 30:5, 9, 20), ${ }^{24}$ and will give Israel a circumcised heart (Dt 30:6) as sign of the renewed covenant in the expected future (McConville 2002:427). The circumcision of the heart is not a condition for the return to God and back home to the promised land; it is a condition for the relaunching of the journey after return, granted by God in his grace (Cook 2015:215-216). But from the postexilic perspective of the actual audience, the heart operation did not seem yet to have taken place; it remained a gift to be expected in the eschatological future. Return to the land lost, did not yet lead to a life attracting the interested attention of the nations (Turner 2013:211).

The loss of land was not the end of the journey that started in Egypt; the reversed exodus would be reversed again (Dt 30:3-5). Remarkably, the sole, clearly symbolical identification of the locality of their exile, Egypt, comes at the end, in Deuteronomy 28:68. No reference is made to any other exilic locality. The loss of land and the dispersion among the nations could occur at any moment in the future. The threat functioned for the implied audience as a constant reminder of its reality, having already experienced a reversal of the exodus after the disaster at Kadesh-Barnea (Dt 1:40). The Egyptian bondage was for them within living memory. For the actual audience in the postexilic era, a final judgement had become a reality in the Babylonian exile, still within their living memory, but Moses' warning (Dt 28:68) did not lose its relevance for the people's continued journey forwards into the eschatological future. God's history of judgement and restoration had not yet come to its uttermost conclusion.

\section{The Deuteronomic roots of Malachi's eschatology}

The journey metaphor can be usefully employed in Malachi as well. Since the start in Egypt, God's journey with Israel had moved through the highs and lows of covenant history (Ml 1:2-5), as the Deuteronomistic history and the pre-exilic prophets testify. The Torath Mosheh as guide appeared to have been accurate and indispensable for the people to stay on course and not to lose direction (Dt 18:22). Despite the differences between the pre-exilic and postexilic stages of the journey, its goal remained unchangeable: to become a blessing to the nations among whom God's name, Yahweh Tsebaōth, would be worshipped (Ml 1:5, 11, 14). The Torath Mosheh would be as indispensable a guide into the postexilic eschatological future, as it was into the future of the pre-exilic redemptive past (Dt 18:22).

In this section, two issues are attended to. Firstly, attention will be paid to the differences in context between the two audiences using the Torath Mosheh as a light on their path. Secondly, conclusions will be drawn from the comparison of Malachi's and Deuteronomy's future prospects.

24.See Hwang (2012:73-80) for the identification of the 'fathers' in Deuteronomy 30. 


\section{The different contexts}

The historical contexts of both audiences using the Torath Mosheh as guide on their common journey, the implied and the actual ones, could not have been more different. The following differences between them should be noted.

Firstly, in Malachi the promised land, known as the Persian province Yehud, was reduced in space and occupied by foreign nations. The reversal of the exodus (Dt 28:68) was once again reversed, but the return to the land lost did not lead to the returnees to repossessing it, in accordance with the patriarchal promise in Genesis 12:3; 15:17-21. The other patriarchal promise of becoming a people as numerous as the sand on the seashore, also did not come true in the postexilic era: only a numerically very small portion of the exiles (20 000 to 30000 people) returned in $539 \mathrm{BCE}$ and following years. ${ }^{25}$

Differently from Deuteronomy, not the whole nation but only the returned remnant was addressed by Malachi as a consequence of the divine judgements in the 8th and 6th century BCE. Among them, he differentiated between the God-forsakers and the God-seekers: the first awaited judgement on the Day of the Lord, envisioned as a burning furnace leaving nothing but ashes; the others, actually a remnant of a remnant but representing all Israel, awaited eschatological peace beyond judgement as a refiners fire. ${ }^{26}$

The realisation of the third patriarchal promise to become a blessing to the nations, seemed even more out of reach of the postexilic audience than it ever was for the implied one, despite Malachi's awareness that Yahweh Tsebaōth will be worshipped one day among the nations (Ml 1:5, 11,14) (Wielenga 2019:5). The absence in Malachi of clear references to Israel's calling among the nations despite its awareness of the worship of Yahweh Tsebaōth among them, is not evidence of a nationalistic ideology as allegedly also found in Ezra-Nehemiah (Wielenga 2013). It is instead a matter of getting their priorities right: without spiritual renewal, the Jewish remnant population in Persian Yehud would not be of use as a blessing to the nations.

Secondly, the places of exile are not identified in Deuteronomy; the usual identification with Assur, Babylon and Persia would not have made sense to the implied audience. This anonymity has a parallel in Deuteronomy 12, where the location of the place chosen by God to establish his name for worship (Dt 12:5) is also not named. ${ }^{27}$ Not its geographic location but its religious destination was decisive: a place chosen by him to establish his name for worship. What counted in Deuteronomy was the religious destination of the places of deportation: they were locations where God would not be worshipped (Dt 28:64); the patriarchal promises would be completely reversed there.

25 See Rom-Shiloni (2008) for the recent scholarly discussion about exile and return and Rom-Shiloni (2019) for the discussion about the identity of the returned exiles as people of God. Finkelstein (2016:9)

26.Self-evidently, Deuteronomy 'does not add much to a development of the "remnant" motif' (Turner 2013:219). The restoration of all Israel is envisioned.

27.See here also Block (2011b:106-108): The focus is rather on the person dwelling there than on the place itself.
The actual audience, like the one in Malachi's time, had both locations clearly identified; however, for them too, their religious destination was decisive. Going into the unknown future, both audiences needed this information to stay on course. $^{28}$

Thirdly, no mention is made in Malachi of the circumcision of Israel's heart, but there is an allusion to the reality of the new covenant related to it (Ml 3:20). The heart condition of the returned exiles seemed to be unchanged, compared with its pre-exilic condition. The fulfilment of the promise in Deuteronomy 30:6, confirmed by prophets like Jeremiah (31:33-34) or Ezekiel (36:26-27), has apparently been delayed as well. One could assume a link between the divine circumcision of the nation's heart and its divine judgement as a refiner's fire on the eschatological Day of the Lord. Both are decisive interventions in an increasingly more eschatological covenant history by a just but compassionate God. Both events refer to the promised future of harmony between God and his people in the land promised to their ancestors. It could be that in a final analysis, both events refer to the same theological reality, but with this distinction that the circumcision of the heart refers to the new reality of peace beyond divine judgement, and the refiner's fire to the purification process as the way through divine judgement.

\section{Conclusion}

The following conclusions are drawn from comparing Malachi's eschatological prophecies with Deuteronomy's judgement promises of loss of land, dispersion among the nations, and restoration beyond at an unspecified time in the future.

Firstly, the journey started by God with the ancestors and which continued through places like Horeb and Moab, will be completed, be it with decreased numbers and in a reduced land and not in the present time, but in the eschatological future $(\mathrm{Ml} 1: 5,11,14 ; 3: 20)$. The detours and blockades during the journey did not and will not prevent Yahweh Tsebaōth from reaching his goal: his people being a blessing to the nations, attracting them to worship him. Malachi and his community must have been encouraged by the teachings of the Torath Mosheh to continue their journey with God.

Secondly, the Deuteronomic curses regarding future loss of land, a divine judgement over persistent covenant infidelity, are still operative in the postexilic context. The Babylonian exile was not the conclusion of the history of divine judgement, but a calamitous halfway station during the journey, that they only could have passed by the grace of a compassionate God. This God did not forget his promises to the patriarchs, confirmed at the well-known stopping places during the journey like Horeb, Moab, Shechem or Zion. The anonymous exilic locations in Deuteronomy turned in Malachi into

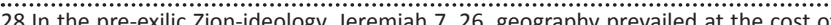
spirituality: the geography of the place (Zion). Zion was more important than its theological significance: to worship God who had established his name there. See Wielenga (1990:117-121) for a short introduction into this ideology as nationalistic Yahwism. 
eschatological destinations, envisioned with (proto-) apocalyptic images as a burning furnace (Ml 3:19) and a refiner's fire (Ml 3:2). The announced future judgement on the eschatological Day of the Lord would be much more severe than the historical one experienced within living memory in Babylon and Persia: it would be the ultimate one, even though the faithful remnant would come through and enjoy the promised peace with a circumcised heart (Ml 3:20, 24), following Deuteronomy 4:29-31 and 30:1-10 (Wielenga 2016:7).

Thirdly, the delay-intended eschatology of Malachi is predicated on the prolonged fulfilment history of the Deuteronomic judgement and restoration promises. As the actual audience could learn from the Deuteronomistic history, God did not hurry to execute judgement, deserved as it may have been, but he is slow to anger (Ex 34:6-7). He postponed it whenever he could, creating space for Israel to return to him with judgement as an instrument of discipline rather than of final punishment. ${ }^{29}$ The Babylonian exile should be interpreted in terms of this prolonged history of judgement and restoration. This history is then the model that shaped Malachi's prophecy of the delayed advent of the Day of the Lord in the eschatological future. Even though the eschatological judgement would be final for the Godforsakers, for the God-seekers it would be a disciplinary experience; they would come through purified. The Deuteronomistic history testifies to the delay of judgement as a foundational component of God's covenant dealings with his people in history.

Fourthly, unsurprisingly the eschatology in Malachi is no less theocentric and temple-based than the Deuteronomic Torath Mosheh in its teachings about the developments of Israel's journey into the future, with a God who requires sole worship from his people at the places chosen by him. This worship guarantees that the journey will be completed at his time.

\section{Epilogue}

The journey metaphor elucidates not only the message of Deuteronomy, but of Malachi as well. It reflects the eschatological propensity of redemptive history, as narrated in the Old but no less in the New Testament. In Malachi, the continuation of God's journey with his people is confirmed, by the promise of the advent of the Lord to his temple, preceded by the arrival of the prophet Elijah, identified in the New Testament as John the Baptist (Mt 11:14; Lk 1:17) (Wielenga 2018:5-6). By this it facilitates the acknowledgment of Jesus of Nazareth as the announced Lord, whose arrival ushered in the eschaton, the Kingdom of heaven (Mt 3:2; 4:17). ${ }^{30}$

29.Judges $2: 1-5,6-23$ is one example of many, testifying to God's faithfulness as basis for the history of delay.

30.From a New Testament perspective, it is possible to sketch the course of the final lap of the journey to its eschatological destination, assisted by the Torath Mosheh (cf. Mt 5:17; 24:36-51; Rv 21:1-8).

\section{Acknowledgements Competing interests}

The author declares that he has no financial or personal relationships that may have inappropriately influenced him in writing this article.

\section{Author's contributions}

I declare that I am the sole author of this research article.

\section{Ethical considerations}

This article followed all ethical standards for research without direct contact with human or animal subjects.

\section{Funding information}

This research received no specific grant from any funding agency in the public, commercial, or not-for-profit sectors.

\section{Data availability}

The authors confirm that the data supporting the findings of this study are available within the article.

\section{Disclaimer}

The views and opinions expressed in this article are those of the author and do not necessarily reflect the official policy or position of any affiliated agency of the author.

\section{References}

Arnold, B.T., 2010, 'Deuteronomy as the ipsissima vox of Moses', Journal of Theological Interpretation 4(1), 53-74.

Arnold, B.T., 2017, 'The book of Deuteronomy: Pseudepigrapha, pseudonymity, or something else altogether?', in D.I. Block \& R.L. Schultz (eds.), Sepher Torath Mosheh: Studies in the composition and interpretation of Deuteronomy, pp. 139-160, Hendrickson, Peabody, MA.

Assis, E., 2012, 'Mutual recriminations: God and Israel in the Book of Malachi', Scandinavian Journal of the Old Testament: An International Journal of Nordic Theology 26(2), 207-219. https://doi.org/10.1080/09018328.2012.730203

Block, D.I., 2001, 'Recovering the voice of Moses: The genesis of Deuteronomy', Journal of Evangelical Theological Studies 44(3), 385-408.

Block, D.I., 2011a, 'The privilege of calling: The Mosaic paradigm for missions', in D.I. Block (ed.), How I love your Torah, o Lord. Studies in the book of Deuteronomy, pp. 140-161, Cascade Books, Eugene, OR.

Block, D.I., 2011b, 'The joy of worship: The Mosaic invitation to the presence of God', in D.I. Block (ed.), How I love your Torah, o Lord. Studies in the book of Deuteronomy, pp. 98-117, Cascade Books, Eugene, OR.

Block, D.I., 2013, 'Gog and Magog in Ezekiel's eschatological vision', in D.I. Block (ed.), Beyond the river Chebar: Studies in kingship and eschatology in the book of Ezekiel, pp. 95-125, Clark, Cambridge.

Block, D.I., 2017, 'Hearing Galatians with Moses: An examination of Paul as a second and seconding Moses', in D.I. Block \& R.L. Schultz (eds.), Sepher Torath Mosheh: Studies in the composition and interpretation of Deuteronomy, pp. 338-374, Hendrickson, Peabody, MA.

Block, D.I. \& Schultz, R.L. (eds.), 2017, Sepher Torath Mosheh: Studies in the composition and interpretation of Deuteronomy, Hendrickson, Peabody, MA.

Coetsee, A.J., 2019, 'Yahweh and Israel in terms of the concept of life in Deuteronomy', Old Testament Essays, 32, 1, 101-126.

Cook, S.L., 2015, Reading Deuteronomy. A literary and theological commentary, Smyth \& Helwys Publishing, Macon, GA

Finkelstein, I., 2016, 'Jerusalem and Judah 600-200 BCE: Implications for understanding Pentateuchal texts', in P. Dubovsky, D. Markl \& J-P. Sonnet (eds.), The fall of Jerusalem and the rise of the Torah, pp. 3-18, Mohr Siebeck, Tuebingen.

Gile, J., 2013, 'Deuteronomy and Ezekiel's theology of exile', in J.S. DeRouchie, J. Gile \& K.J. Turner (eds.), For our good always: Studies on the message and influence of Deuteronomy, pp. 287-306, Eisenbrauns, Winona Lake, IN. (Fs.-D.I. Block). 
Hays, C.M. (ed.), 2016, When the Son of Man didn't come: A constructive proposal on the Delay of the Parousia, Fortress Press, Minneapolis, MN.

Hwang, J., 2012, The rhetoric of remembrance: An investigation of the 'fathers' in Deuteronomy, Eisenbrauns, Winona Lake, IN.

Labuschagne, C.J., 1997, Deuteronomium deel 3, Callenbach, Nijkerk. (Prediking van het Oude Testament).

McConville, J.G., 1994, 'Time, place and the Deuteronomic altar-law', in J.G. McConville \& J.G. Millar (eds.), Time and place in Deuteronomy, pp. 89-139,

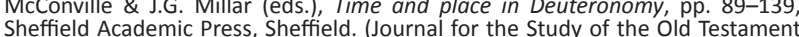
Sheffield Academic Press,
Supplement Series 179).

McConville, J.G., 2002, Deuteronomy, Apollos, Nottingham. (Apollos Old Testament Commentary).

McKenzie, S.L. \& Wallace, H.N., 1983, 'Covenant themes in Malachi', Catholic Biblical Quarterly 45, 549-563.

Millar, J.G., 1994, 'Living at the place of decision: Time and place in the framework of Deuteronomy', in J.G. McConville \& J.G. Millar, Time and place in Deuteronomy pp. 15-88, Sheffield Academic Press, Sheffield. (Journal for the Study of the Old Testament Supplement Series 179).

Miller, P.D., 1990, Deuteronomy, Interpretation, John Knox Press, Louisville, KY.

O'Brien, J.M., 1990, Priest and Levite in Malachi, Scholars Press, Atlanta, GA. (SBL Dissertations Series121).

Otto, E., 2007, 'Hoofdlijnen van het recente onderzoek van het boek Deuteronomium', in K. Spronk (ed.), Cahier 23: Deuteronomium, Skandalon, Vught. (Amsterdamse Cahiers voor Exegese van de Bijbel en zijn Tradities).

Richter, S.L., 2007, 'The place of the name in Deuteronomy', Vetus Testamentum 57(3), 342-366. https://doi.org/10.1163/156853307X215518

Rom-Shiloni, D., 2008, 'Deuteronomic concepts of exile interpreted in Jeremiah and Ezekiel', in C. Cohen (ed.), Birkat Shalom: Studies in the Bible, Ancient Near Eastern literature, and Postbiblical Judaism, pp. 101-123, Eisenbrauns, Winona Lake, IN. (Fs-S.M. Paul).

Rom-Shiloni, D., 2019, 'What is Persian in late sixth century BCE prophetic literature?', in R.J. Bautch \& M. Mackowski (eds.), On dating biblical texts to the Persian period: Discerning criteria and establishing epochs, pp. 31-54, Mohr Siebeck, Tübingen.

Rose, W.H., 2012, 'Zechariah: Prophet of the king of Jerusalem and all the earth', in H.G.L. Peels \& S.D. Snyman (eds.), The lion has roared: Theological themes in the prophetic literature of the Old Testament, pp. 183-196, Pickwick Publications, Eugene, OR.

Skafte, N.M., 2013, 'The holy seed of Israel: Group identity and cultural imagery in Ezra 9-10', MTh unpublished thesis, Oxford University, Oxford. (Hebrew and Jewish Studies).

Smith, G.V., 2013, 'The influence of Deuteronomy on intercessory prayers in Ezra and Nehemiah', in J.S. DeRouchie, J. Gile \& K.J. Turner (eds.), For our good always: Studies on the message and influence of Deuteronomy, pp. 345-364, Eisenbrauns, Studies on the message and influen
Winona Lake, IN. (Fs-D.I. Block).

Snyman, S.D., 2015, Malachi, Peeters, Leuven. (Historical Commentary on the Old Testament).

Sonnet, J.-P., 2012, 'The fifth book of the Pentateuch: Deuteronomy in its narrative dynamic', Journal of Ancient Judaism 3(2), 197-234. https://doi.org/10.30965/ 21967954-00302005
Sonnet, J.-P., 2016, 'The siege of Jerusalem between rhetorical maximalism (Deuteronomy 28) and narrative minimalism (2 Kings 25)', in P. Dubovský, D. Markl \& J.-P. Sonnet (eds.), The fall of Jerusalem and the rise of Torah, pp. 73-88, Mohr$\&$ J.-P. Sonnet (eds.)
Siebeck, Túbingen.

Tiemeyer, L.-S., 2005a, 'Giving voice to Malachi's interlocutors', Scandanavian Journal of the Old Testament: An International Journal of Nordic Theology 19(2), 173-192. https://doi.org/10.1080/09018320500472652

Tiemeyer, L.-S., 2005b, 'Prophecy as a way of cancelling prophecy - The strategic uses of foreknowledge', Zeitschrift für alttestamentliche Wissenschaf 117(3), 329-350. https://doi.org/10.1515/zatw.2005.117.3.329

Turner, K.J., 2011, The death of deaths in the death of Israel: Deuteronomy's theology of exile, Wipf \& Stock, Eugene, OR.

Turner, K.J., 2013, 'Deuteronomy's theology of exile', in J.S. DeRouchie, J. Gile \& K.J. Turner (eds.), For our good always: Studies on the message and influence of Deuteronomy, pp. 189-222, Eisenbrauns, Winona Lake, IN. (Fs- D.I. Block).

Vang, C., 2011, 'Deuteronomy and the notion of exile', in S. Rieckert \& J. Steinberg (eds.), Das heilige Herz der Torah, pp. 23-40, Shaker Verlag, Aachen. (Fs-H.J. Koorevaar).

Vogt, P., 2003, 'Religious concepts in the theology of Deuteronomy: A reappraisal of the Deuteronomic theology and the significance of Torah', PhD thesis, Gloucestershire University, Cheltenham.

Vogt, P., 2013, 'These are the words Moses spoke: Implied audience and a case for a pre-monarchical dating of Deuteronomy', in J.S. DeRouchie, J. Gile \& K.J. Turner (eds.), For your good always: Studies in the message and influence of Deuteronomy, pp. 61-80, Eisenbrauns, Winona Lake, IN. (Fs- D.I. Block).

Weyde, K.W., 2000, Prophecy and teaching: Prophetic authority, form problems, and the use of traditions in the book of Malachi, De Gruyter, Berlin.

Wielenga, B., 1990, 'Volk van het land als missiologisch model: Oude Testament en zending in Zuidafrikaanse kontekst', unpublished DTh thesis, UNISA, Pretoria.

Wielenga, B., 1998, Verbond en zending: Een verbondsmatige benadering van zending, Mondiss, Kampen.

Wielenga, B., 2013, 'Renewal and reconstruction: Holy Writ in Ezra-Nehemiah - A missional reading', In die Skriflig/In Luce Verbi 47(1), a72. https://doi.org/104102/ ids.v47i1.72

Wielenga, B., 2016, 'Eschatology in Malachi: The emergence of a doctrine', In die Skriflig / In Luce Verbi 50(1), a2091. https://doi.org/104102/ids.v50i1.2091

Wielenga, B., 2017, 'On the margins of redemptive history: The antiquarian nations in Deuteronomy 2', Theologia Reformata 60(3), 46-63.

Wielenga, B., 2018, 'The delay of the Day of the Lord in Malachi: A missional reading', In die Skriflig / In Luce Verbi 52(1), a2362. https://doi.org/104102/ids.v52i1.2362

Wielenga, B., 2019, 'Remember the Law of Moses: Malachi 3:22 in prophetic eschatology, with a missional postscript', In die Skriflig / In Luce Verbi 53(1), a2452. https://doi.org/104102/ids.v53i1.2452

Wielenga, B., 2020, 'The gēr (immigrant) in postexilic prophetic eschatology: The perspectives of Ezekiel 47:22-23 and Malachi 3:5', In die Skriflig/In Luce Verbi 54(1), a2617. https://doi.org/104102/ids.v54i1.2617

Wright, C.H.J., 2006, The mission of God: Unlocking the Bible's grand narrative, IVP Academic, Downers Grove, IL. 